\title{
Kinetic Spectrophotometric Determination of Traces of Molybdenum(VI) by Its Inhibitory Effect on the Oxidation of 4-Hydroxycoumarine by Potassium Permanganate
}

\author{
Ružica J. Micıć, ${ }^{\dagger}$ Ranko M. Simonović, and Branka B. Petković \\ Faculty of Natural Sciences and Mathematics, University of Priština, 38220 Kosovska Mitrovica, \\ Serbia and Montenegro
}

\begin{abstract}
The present paper describes a simple, selective and sensitive kinetic method for the determination of trace amounts of molybdenum(VI) based on its inhibitory effect on the reaction oxidation of 4-hydroxycoumarine by $\mathrm{KMnO}_{4}$ in the presence of hydrochloric acid, at $\mathrm{pH} 1.75$ at $25^{\circ} \mathrm{C}$. The rate of the indicator reaction was followed spectrophotometrically by measuring the decrease in the absorbance of $\mathrm{KMnO}_{4}$ at $525 \mathrm{~nm}$. The development method includes optimization of the reagent concentration and temperature. The calibration graph was linear in the range of concentrations from 20 to 200 $\mathrm{ng} / \mathrm{cm}^{3}$ of molybdenum(VI). The probable relative error was in the interval $3.10-10.52 \%$ for the concentration range of $200-20 \mathrm{ng} / \mathrm{cm}^{3}$ molybdenum(VI), respectively. The interference effects of the foreign ions were determined to assess the selectivity of the method. The developed method was found to have relatively good selectivity, sensitivity, simplicity and rapidity. The proposed method was applied to the determination of molybdenum(VI) in a particular type of steel and alloy (hastelloy).
\end{abstract}

(Received July 5, 2005; Accepted November 28, 2005)

\section{Introduction}

Molybdenum is a bio-essential element, and its occurrence in water samples is of interest from both environmental and chemical points of view. Molybdenum has an extremely important role in the metabolism of plants. ${ }^{1}$ Molybdenum is added in trace amounts to fertilizers to stimulate plant growth. On the other hand, excess exposure can result in toxicity to animals and humans. ${ }^{2}$ Molybdenum poisoning causes severe gastrointestinal irritation with diarrhea, coma ruminants and death from cardiac failure. ${ }^{2}$ From an analytical point of view, it is important to find a selective and sensitive method for determination of molybdenum(VI). This can be carried out by atomic absorption spectrometry at the $313.3 \mathrm{~nm}$ molybdenum resonance line, using either flame (nitrogen oxide-acetylene) or electrothermal atomization as well as plasma emission. Both methods are disadvantageous in terms of cost and the instruments used in routine analysis. ${ }^{3-6}$

Sensitive techniques for the determination of trace amounts of molybdenum include inductively coupled plasma-atomic emission spectrometry (ICP/AES) $)^{7-9}$ and neutron activation analysis (NAA). ${ }^{10,11}$ The high instrumental costs and need for preconcentration and/or separation are common disadvantages.

Spectrophotometric methods in which a number of reagents have been proposed in aqueous solutions are most commonly used for the determination of molybdenum. Most of them show poor selectivity or sensitivity, or the conditions of the color reaction, such as the $\mathrm{pH}$, must be strictly controlled in order to obtain reliable results. ${ }^{12-14}$

On the other hand, kinetic methods of analysis are very

† To whom correspondence should be addressed.

E-mail: ruzicamicic@yahoo.com simple, and inexpensive alternatives for molybdenum determination. ${ }^{15-20}$ The aim of this study was to develop a simple kinetic-spectrophotometric method for the determination of traces of molybdenum(VI). An indicator reaction (oxidation 4-hydroxycoumarine by $\mathrm{KMnO}_{4}$ ) has not previously been used for the kinetic determination of traces of molybdenum(VI) This paper reports on its use in a simple, sensitive, selective and inexpensive kinetic method for the determination of trace amounts of molybdenum(VI) based on its inhibitory effect on the reaction oxidation of 4-hydroxycoumarine by $\mathrm{KMnO}_{4}$ in the solution at $\mathrm{pH} 1.75$, at $25^{\circ} \mathrm{C}$. The reaction is carried out by spectrophotometric measurements of the dependence of the absorbance $(A)$ at $525 \mathrm{~nm}$ on time $(s)$. The rate of the reaction decreases proportionally with increasing concentration of molybdenum(VI).

\section{Experimental}

\section{Apparatus}

A UV-VIS Perkin-Elemer Lambda 15 spectrophotometer with thermostated cylindrical cells (length of $10 \mathrm{~cm}$ ) was used for absorbance measurements.

The $\mathrm{pH}$ was measured by means of a radiometer (PHM 29Bb pH-meter) and a combined glass-calomel electrode (GK2311C). Sigma buffers, $\mathrm{pH} 7 \pm 0.01$ and $\mathrm{pH} 4 \pm 0.01$, were used to calibrate the $\mathrm{pH}$ meter. All solutions were kept in a thermostatic waterbath at $25^{\circ} \mathrm{C}$ before beginning the reaction. Spectrophotometric measurements were done at a wavelength of $525 \mathrm{~nm}$.

\section{Reagents}

Analytical-grade reagents, deionized water and polyethylene vessels were used throughout this study. A solution of $\mathrm{KMnO}_{4}$ of $2 \times 10^{-2} \mathrm{~mol} / \mathrm{dm}^{3}$ was prepared from an ampoule produced by 


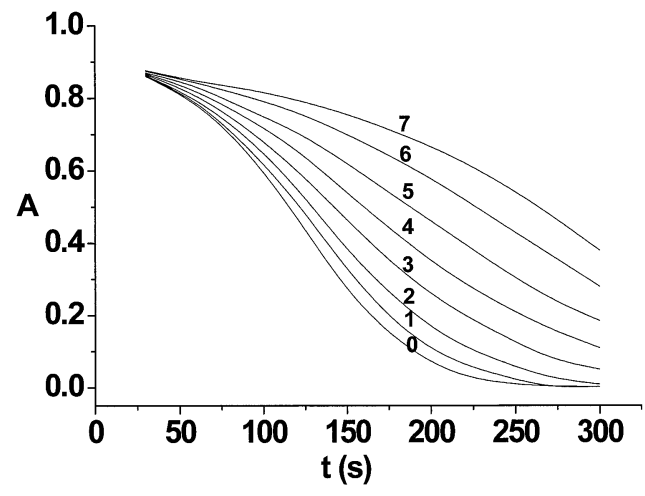

Fig. 1 Effect of time on the determination of $\mathrm{Mo}(\mathrm{VI})$. Experimental conditions: $3.6 \times 10^{-5} \mathrm{~mol} / \mathrm{dm}^{3}$ of $\mathrm{KMnO}_{4} ; 3 \times 10^{-5}$ $\mathrm{mol} / \mathrm{dm}^{3}$ of 4-hydroxycoumarine; $\mathrm{pH}, 1.75 ; 25^{\circ} \mathrm{C}$. $\mathrm{Mo}(\mathrm{VI})$ concentration: 0,$0 ; 1,20 ; 2,50 ; 3,100 ; 4,150 ; 5,200 ; 6,300 ; 7,400$ $\mathrm{ng} / \mathrm{ml}$.

"Merck" by dissolving in a calibrated volumetric flask. The solution of $\mathrm{KMnO}_{4}$ was saved in a dark reagent flask. Before the experiment, the concentration of the solution was checked spectrophotometrically at $525 \mathrm{~nm}$. Further dilutions were made using this stock solution when needed (dilution was done with deionized water). A $1 \times 10^{-3} \mathrm{~mol} / \mathrm{dm}^{3}$ solution of 4hydroxycoumarine was prepared by dissolving $0.16414 \mathrm{~g}$ of the solid in $10 \mathrm{~cm}^{3}$ of $0.1 \mathrm{M} \mathrm{NaOH}$ to improve the solubility of 4hydroxycoumarine and diluting with deionized water to $1 \mathrm{dm}^{3}$ in a calibrated volumetric flask. The solution of $\mathrm{HCl}(0.2$ $\mathrm{mol} / \mathrm{dm}^{3}$ ) was prepared form a $37 \%$ concentrated $\mathrm{HCl}$ solution. A standard solution of molybdenum(VI) $1000 \mu \mathrm{g} / \mathrm{cm}^{3}$ was prepared by dissolving $2.0425 \mathrm{~g}\left(\mathrm{NH}_{4}\right)_{2} \mathrm{MoO}_{4}$ in $1 \mathrm{dm}^{3}$ deionized water, with conductivity less than $0.5 \mu \mathrm{S}$. The exact concentration was determined volumetrically.

\section{Procedure}

The initial concentration of each of the reactants was in turn systematically varied, while the initial concentrations of the reactants were kept constant. Selected volumes of the reactants were put into a $20 \mathrm{~cm}^{3}$ standard flask in the order 4hydroxycoumarine, $0.2 \mathrm{M}$ solution of $\mathrm{HCl}$, standard solution of molybdenum(VI) and deionized water to make up exactly to the predetermined volume. The flasks were kept in a thermostat for $10 \mathrm{~min}$ at a temperature of $25 \pm 0.1^{\circ} \mathrm{C}$ before beginning the reaction. The solution was then made up to the mark with $\mathrm{KMnO}_{4}$, and vigorously shaken, and a chronometer was simultaneously turned on. The cell of the photometer was rinsed well and filled with the prepared solution. During the reaction, the color of the solution disappeared and a colorless reaction product was formed. The absorbance $(A)$ at $525 \mathrm{~nm}$ was measured after adding a solution of $\mathrm{KMnO}_{4}$, starting from $30 \mathrm{~s}$ every $15 \mathrm{~s}$ over a period of $5 \mathrm{~min}$ of the reaction. The initial concentrations of the reagent solutions after dilution to $20 \mathrm{~cm}^{3}$ were: $1 \times 10^{-5}-4 \times 10^{-5} \mathrm{~mol} / \mathrm{dm}^{3}$ of 4-hydroxycoumarine; $1.5 \times$ $10^{-5}-4.5 \times 10^{-5} \mathrm{~mol} / \mathrm{dm}^{3} \mathrm{KMnO}_{4} ; 1.0 \times 10^{-2}-5.62 \times 10^{-2}$ $\mathrm{mol} / \mathrm{dm}^{3} \mathrm{H}_{3} \mathrm{O}^{+}$ions; $20-200 \mathrm{ng} / \mathrm{cm}^{3}$ molybdenum(VI).

The dependence absorbance $(A) v s$. time $(t)$ is presented in Fig. 1. The rate of the reaction decreases proportionally with increasing concentration of molybdenum(VI). The variation in the absorbance of $\mathrm{KMnO}_{4}$ vs. time was started to be measured $30 \mathrm{~s}$ after the addition of $\mathrm{KMnO}_{4}$ in the solution. The differential variant of the fixed time method was used for processing the obtained kinetic data. ${ }^{21,22}$ The measured kinetic

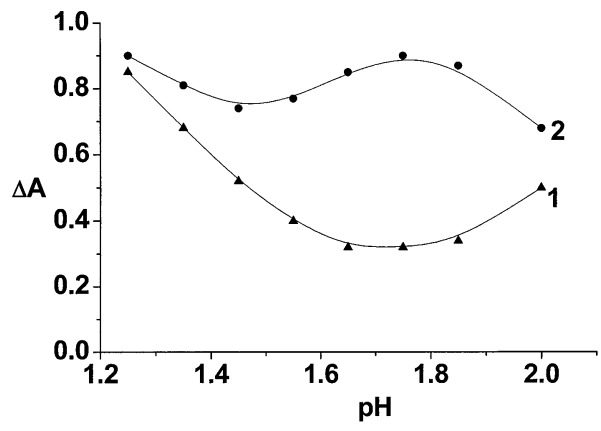

Fig. 2 Dependence of the reaction rate on the $\mathrm{pH}$. Initial conditions: $3.6 \times 10^{-5} \mathrm{~mol} / \mathrm{dm}^{3}$ of $\mathrm{KMnO}_{4} ; 3 \times 10^{-5} \mathrm{~mol} / \mathrm{dm}^{3}$ of 4 hydroxycoumarine. Mo(VI) concentration: curve $1,400 \mathrm{ng} / \mathrm{cm}^{3}$; curve $2,0 \mathrm{ng} / \mathrm{cm}^{3} ; 25 \pm 0.1^{\circ} \mathrm{C}$.

parameter was $\Delta A$ vs. time $(s)$, the difference between the absorbance of the indicating and inhibiting reactions corresponding to the same reading times (195 s). From Fig. 1, it follows that the maximum difference in the absorbance between the indicating (curve 0) and inhibiting reactions for different concentration of molybdenum(VI) (curves 1 - 7) occurred at $195 \mathrm{~s}$.

\section{Recommended procedure for measurements}

First, $3 \mathrm{~cm}^{3}$ of a $1 \times 10^{-3} \mathrm{M}$ prepared solution of 4hydroxycoumarine, $9 \mathrm{~cm}^{3}$ of a $0.2 \mathrm{M}$ solution of $\mathrm{HCl}$, and 20 $\mathrm{cm}^{3}$ of deionized water were placed in a reagent flask. From that mixture, $6.4 \mathrm{~cm}^{3}$ was taken and put in three polyethylene vessels (I, II, and III). To the first vessel (I) was added $10 \mathrm{~cm}^{3}$ deionized water, and to the second vessel (II) was added $10 \mathrm{~cm}^{3}$ of the solution sample of molybdenum(VI). The solutions were thermostated at $25 \pm 0.1^{\circ} \mathrm{C}$ before the reaction began. A solution of $\mathrm{KMnO}_{4}\left(2 \times 10^{-4} \mathrm{M}\right)$ was prepared by diluting a standard solution of $\mathrm{KMnO}_{4}\left(2 \times 10^{-2} \mathrm{M}\right)$, and was also thermostated for $10 \mathrm{~min}$ before the reaction began at $25 \pm 0.1^{\circ} \mathrm{C}$; then, to the first vessel (I) and to the second vessel (II) were added $3.6 \mathrm{~cm}^{3}$ of a $2 \times 10^{-4} \mathrm{M}$ solution of $\mathrm{KMnO}_{4}$, and $\Delta A$ was measured for $195 \mathrm{~s}$ after the reaction began. An unknown concentration of Mo(VI) was calculated by Eq. (1). Then, $5 \mathrm{~cm}^{3}$ of the sample solution of molybdenum(VI) and $5 \mathrm{~cm}^{3}$ of the standard solution of molybdenum(VI) in equal concentrations were placed in vessel (III); after adding $\mathrm{KMnO}_{4}, \Delta A$ was measured for $195 \mathrm{~s}$, after beginning of reaction. All procedures mentioned above were carried out at a temperature of $25 \pm$ $0.1^{\circ} \mathrm{C}$. The absorbance of the colored solution was measured at $525 \mathrm{~nm}$. Finally, the unknown concentration of molybdenum(VI) was calculated by the method of standard addition.

\section{Results and Discussion}

\section{Effect of the reaction parameters}

In order to establish the optimum conditions for the determination of molybdenum(VI), the influence of the $\mathrm{pH}$ as well as the $\mathrm{KMnO}_{4}$ and 4-hydroxycoumarine concentrations were studied on the indicating and inhibiting reactions by the fixed-time method.

Keeping all other experimental parameter constant, we studied the influence of the $\mathrm{pH}$ on the system in the range 1.2 - 2.0 (Fig. 2). It can be seen that the greatest difference between the rates of the indicating and inhibiting reactions occurred at $\mathrm{pH} 1.75$, when molybdenum(VI) maximally decreased the reaction rate. 


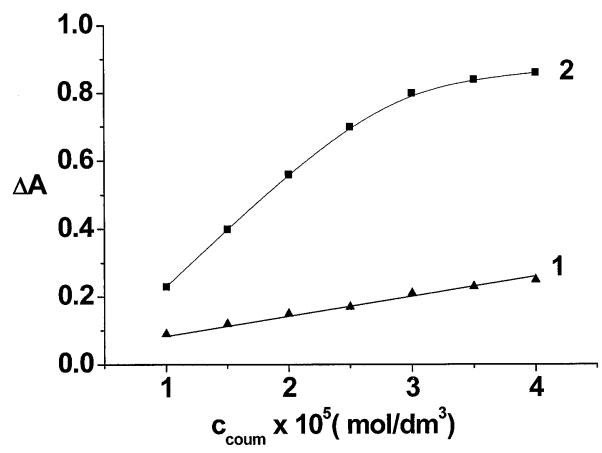

Fig. 3 Dependence of the reaction rate on the 4-hydroxycoumarine concentration. Initial conditions: $3.6 \times 10^{-5} \mathrm{~mol} / \mathrm{dm}^{3}$ of $\mathrm{KMnO}_{4} ; \mathrm{pH}$, 1.75. Mo(VI) concentration: curve $1,400 \mathrm{ng} / \mathrm{cm}^{3}$; curve $2,0 \mathrm{ng} / \mathrm{cm}^{3}$; $25 \pm 0.1^{\circ} \mathrm{C}$.

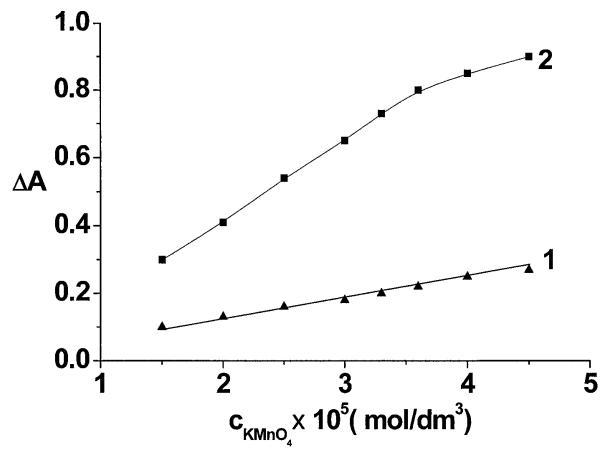

Fig. 4 Dependence of the reaction rate on the $\mathrm{KMnO}_{4}$ concentration. Initial conditions: $3 \times 10^{-5} \mathrm{~mol} / \mathrm{dm}^{3}$ of 4hydroxycoumarine; $\mathrm{pH}, 1.75$. Mo(VI) concentration: curve 1, 400 $\mathrm{ng} / \mathrm{cm}^{3}$; curve $2,0 \mathrm{ng} / \mathrm{cm}^{3} ; 25 \pm 0.1^{\circ} \mathrm{C}$.

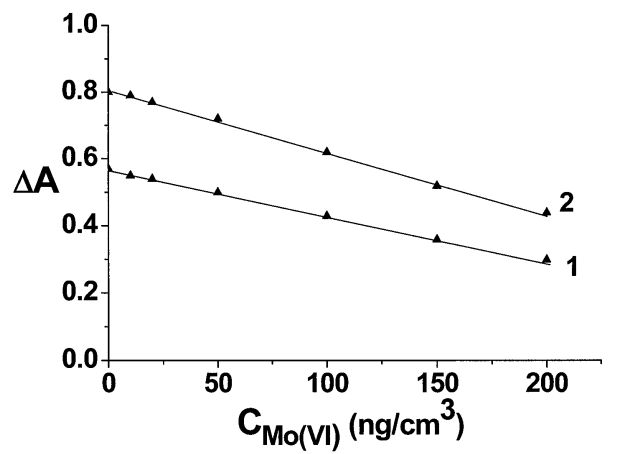

Fig. 5 Dependence of the reaction rate on the $\mathrm{Mo}(\mathrm{VI})$ concentration. Initial conditions, $3.6 \times 10^{-5} \mathrm{~mol} / \mathrm{dm}^{3}$ of $\mathrm{KMnO}_{4} ; 3.0$ $\times 10^{-5} \mathrm{~mol} / \mathrm{dm}^{3}$ of 4-hydroxycoumarine; $\mathrm{pH}, 1.75 ; 1$, temperature 20 $\pm 0.1^{\circ} \mathrm{C} ; 2$, temperature $25 \pm 0.1^{\circ} \mathrm{C}$.

For further work, a $\mathrm{pH}$ of 1.75 was chosen.

The dependence of $\Delta A$ on the 4-hydroxycoumarine concentration is shown in Fig. 3. The maximum difference between the rates of the inhibited and the indicated reactions occurred for concentrations of $3 \times 10^{-5} \mathrm{~mol} / \mathrm{dm}^{3}$ of 4 hydroxycoumarine. For further work, a concentration of 4 hydroxycoumarine of $3 \times 10^{-5} \mathrm{~mol} / \mathrm{dm}^{3}$ was selected as the optimal value.

The dependence of $\Delta A$ on the concentration of $\mathrm{KMnO}_{4}$ is
Table 1 Accuracy and precision of molybdenum(VI) determination

\begin{tabular}{ccccc}
\hline $\begin{array}{c}\text { Taken }(\mu) \\
\left(\mathrm{ng} / \mathrm{cm}^{3}\right)\end{array}$ & $\begin{array}{c}\text { Found }(x) \\
\left(\mathrm{ng} / \mathrm{cm}^{3}\right)\end{array}$ & $n$ & $\frac{100 t s}{\bar{x} \sqrt{n}}, \%$ & $\frac{\bar{x}-\mu}{\mu}, \%$ \\
\hline 20 & 23 & 5 & 10.52 & 15.0 \\
50 & 54 & 5 & 6.44 & 8.0 \\
100 & 94 & 5 & 3.84 & -6.0 \\
200 & 190 & 5 & 3.10 & -5.0 \\
\hline
\end{tabular}

$\bar{x}$, Mean value; $\mu$, true value; $s$, standard deviation; $t$, Student's test for 95\% confidence; $100 t s / x \sqrt{n}$, precision; $(x-\mu) / \mu$, accuracy.

shown in Fig. 4. The maximum difference between the rates of the inhibited and indicated reactions occurred for concentrations of $3.6 \times 10^{-5} \mathrm{~mol} / \mathrm{dm}^{3}$ of $\mathrm{KMnO}_{4}$. For further work, a concentration of $\mathrm{KMnO}_{4}$ of $3.6 \times 10^{-5} \mathrm{~mol} / \mathrm{dm}^{3}$ was selected as the optimal value.

\section{Calibration graph}

For the optimal conditions described above, a calibration graph was prepared at 2 different temperatures of $20 \pm 0.1^{\circ} \mathrm{C}$ (Fig. 5, line 1) and $25 \pm 0.1^{\circ} \mathrm{C}$ (line 2). There is a linear relationship between $\Delta A$ and the molybdenum(VI) concentration from 20 to $200 \mathrm{ng} / \mathrm{cm}^{3}$ at $525 \mathrm{~nm}$. Line 2 at $25 \pm 0.1^{\circ} \mathrm{C}$ is steeper, which makes it more sensitive for the molybdenum(VI) determination. Rigorous control of the temperature is necessary to attain the good precision and accuracy of the results.

Based on calibration graph (2), for $25 \pm 0.1^{\circ} \mathrm{C}$, an unknown concentration of molybdenum(VI) can be determined by the following equation, which was obtained by the least-squares method:

$$
c_{\mathrm{Mo}(\mathrm{VI})}=\frac{0.8-\Delta A}{0.0018}\left(\mathrm{ng} / \mathrm{cm}^{3}\right)
$$

where $\Delta A$ is the change in the absorbance of the indicator substance $\left(\mathrm{KMnO}_{4}\right)$ after $195 \mathrm{~s}$ from beginning the reaction. ${ }^{20,21}$

\section{Accuracy and precision}

In order to assess the precision and accuracy of the proposed method, the reaction rates were determined for five replicate determinations ${ }^{23}$ (Student's criteria) at each of four different molybdenum(VI) concentrations in the range of the calibration graph $\left(20.00,50.00,100.00,200.00 \mathrm{ng} / \mathrm{cm}^{3}\right)$

The probable relative error ranged from $10.52 \%$ to $3.10 \%$ for concentrations of molybdenum(VI) from 20 to $200 \mathrm{ng} / \mathrm{cm}^{3}$. The results are presented in Table 1.

\section{Interference study}

To access the selectivity of the method, the influence of some foreign ions on the inhibited reaction rates was studied, under the optimal conditions mentioned above, at a constant molybdenum(VI) concentration of $200 \mathrm{ng} / \mathrm{cm}^{3}$. The results are summarized in Table 2. This table shows that the $\mathrm{Au}^{3+}$ ion seriously interferes with the determination of $\mathrm{Mo}(\mathrm{VI})$

\section{Application}

The method was applied to the determination of molybdenum(VI) in steel and an alloy (hastelloy), which is resistent in corrosion gases. The obtained amount of molybdenum(VI) in the analyzed sample of steel was $1.61 \%$. The obtained amount of molybdenum(VI) in the analyzed sample of alloy (hastelloy) was $17.70 \%$. The results obtained 
Table 2 Effect of foreign ions on the determination of 200 $\mathrm{ng} / \mathrm{cm}^{3}$ of $\mathrm{Mo}(\mathrm{VI})$

\begin{tabular}{cl}
\hline $\begin{array}{c}\text { Tolerance limit } \\
\text { Foreign ion/Mo(VI) }\end{array}$ & \multicolumn{1}{c}{ Ion added } \\
\hline 104 & $\mathrm{Cl}^{-}, \mathrm{Na}^{+}, \mathrm{K}^{+}, \mathrm{NH}_{4}^{+}, \mathrm{Mg}^{2+}, \mathrm{Sr}^{2+}, \mathrm{Sr}^{2+}, \mathrm{Ba}^{2+}$, \\
& $\mathrm{Ca}^{2+}, \mathrm{NO}_{3}{ }^{-}, \mathrm{SO}_{4}^{2-}, \mathrm{Cl}^{-}, \mathrm{CH}_{3} \mathrm{COO}^{-}$, \\
400 & $\mathrm{Sn}^{2+}, \mathrm{Pb}^{2+}, \mathrm{Hg}^{2+}, \mathrm{Cd}^{2+}, \mathrm{Ni}^{2+}, \mathrm{Co}^{2+}$ \\
250 & $\mathrm{Pd}^{2+}, \mathrm{Pt}^{2+}, \mathrm{Cu}^{2+}, \mathrm{Zn}^{2+}, \mathrm{Ti}^{4+}, \mathrm{Zr}^{4+}$ \\
200 & $\mathrm{Al}^{3+}, \mathrm{Cr}^{6+}$ \\
200 & $\mathrm{Fe}^{3+}$ \\
100 & $\mathrm{Bi}^{3+}, \mathrm{Sb}^{3+}, \mathrm{As}^{5+}$ \\
50 & $\mathrm{PO}_{4}^{3-}, \mathrm{SCN}^{-}, \mathrm{C}_{4} \mathrm{O}_{4}{ }^{2-}$, citrates \\
40 & $\mathrm{Ag}^{+}$ \\
10 & $\mathrm{~V}^{5+}$ \\
5 & $\mathrm{WO}_{4}^{2-}$ \\
1 & $\mathrm{Au}^{3+}$ \\
\hline
\end{tabular}

for both samples are summarized in Table 3. When the results from the proposed method are compared with the results from the AAS measurements for the same samples, it can be concluded that the proposed method is in a good agreement with AAS method. ${ }^{24,25}$ For determining an unknown amount of molybdenum(VI) in samples, the method of standard addition was used.

\section{Conclusion}

This work describes a relatively inexpensive, rapid, simple and sensitive kinetic method for the determination of trace amounts of molybdenum(VI) based on the its inhibitory effect on the reaction oxidation 4-hydroxycoumarine by $\mathrm{KMnO}_{4}$ at $\mathrm{pH} 1.75$. The method was applied to the determination of molybdenum(VI) in steel and an alloy (hastelloy), with a satisfactory sensitivity and selectivity.

\section{Acknowledgements}

This paper, as a part of Project 1211, was supported by the Ministry of Science and Environment Protection, Republic of Serbia.

\section{References}

1. L. S. Hurly, in "Trace Element Analytical Chemistry in Medicine and Biology", ed. P. Bratter and P. Schramel, 1984, Walter de Gruyter, Berlin, 375.

2. S. Langard and T. Norseth, in "Handbook on the Toxicology of Metals", ed. L. Friberg, G. F. Nordberg, and
Table 3 Determination of molybdenum(VI) in samples (\%)

\begin{tabular}{lccc}
\hline \multicolumn{1}{c}{ Sample } & $\begin{array}{c}\text { Proposed }_{\text {method }^{\mathrm{a}}} \\
\text { method }^{\mathrm{a}}\end{array}$ & $\begin{array}{c}\text { RSD, \% } \\
\text { bas }\end{array}$ \\
\hline Steel & 1.61 & 1.56 & 2.70 \\
$93.78 \% \mathrm{Fe}, 1.56 \% \mathrm{Mo}, 2.8 \% \mathrm{Cr}$, & & & \\
$0.92 \% \mathrm{~V}, 0.55 \% \mathrm{Mn}, 0.39 \% \mathrm{C}$ & & & \\
Alloy (hastelloy) & 17.70 & 16.85 & 3.92 \\
& $\begin{array}{l}\text { 14.14\% Cr, 57.86\% Ni, 16.85\% } \\
\text { Mo, 5.15\% W, 6.00\% Fe }\end{array}$ & & \\
\hline
\end{tabular}

a. Average values of 5 separate determinations.

b. RSD for the proposed method.

V. B. Vouk, 1986, Elsevier, Amsterdam.

3. E. Canfranc, A. Abaska, I. Sierra, and M. Marina, J. Pharm. Biomed., 2001, 25, 103.

4. M. Hoenig, Y. Van Elsen, and V. Couter, Anal. Chem., 1985, 58, 777.

5. M. Ternero and I. Gracia, Analyst, 1983, 106, 310.

6. C. L. Cakrabarti, S. Wu, and K. L. Headrick, Z. Anal. Chem., 1986, 323, 730.

7. P. Scharmel, Spectrochim. Acta, 1986, 388, 199.

8. J. Lee, Anal. Chim. Acta, 1983, 152, 141.

9. S. L. Ferreira, H. C. dos Santos, and D. S. de Jesus, Fresenius J. Anal. Chem., 2001, 369(2), 187.

10. R. Zeisler, in "NBS Spetial Publication", 1983, 36, 656.

11. L. Kosta, Talanta, 1982, 29, 985.

12. J. Di and Y. Tu, Talanta, 2001, 55, 783.

13. Z. Li, J. Pan, and T. Jan, Analyst, 2001, 126, 1154.

14. M. Alkan, M. Kharun, and F. Chimilenko, Talanta, 2003, 59, 605 .

15. T. Tomiyasn, Anal. Chim. Acta, 1997, 349, August 29, 1.

16. A. A. Ensafi and A. Safavi, Anal. Lett., 1991, 26, 1057.

17. A. A. Ensafi, Anal. Lett., 1992, 25, 2339.

18. A. A. Ensafi and A. Hagighi, Fresenius J. Anal. Chem., 1998, 360, 535.

19. M. V. Obradovic, S. S. Mitic, D. S. Veselinovic, and D. C. Naskovic, J. Serb. Chem. Soc., 1998, 63, 869.

20. M. J. Ahmed and M. E. Haque, Anal. Sci., 2002, 55, 433.

21. K. B. Yatisimirskii, "Kineticheskie Metody Analiza", 1967, Khimiya, Moskva, 39.

22. H. Muller, M. Oto, and G. Werner, "Katalytishe Methoden in der Spurenanalyse”, 1980, Leipzig.

23. J. N. Miller and J. C. Miller, "Statistics and Chemometrics for Analytical Chemistry", 2000, Pearson Education Limited, England.

24. J. R. Dean, "Methods for Environmental Trace Analysis", 2003, Newcastle, UK.

25. The Perkin-Elmer Corporation, "Analytical Methods for Atomic Absorption Spectroscopy", 1996. 